\title{
Bacteriocins of lactic acid bacteria: extending the family
}

\author{
Patricia Alvarez-Sieiro ${ }^{1,2}$ • Manuel Montalbán-López ${ }^{1}$. \\ Dongdong $\mathrm{Mu}^{1,3} \cdot$ Oscar P. Kuipers ${ }^{1}$
}

Received: 23 November 2015 /Revised: 18 January 2016/Accepted: 22 January 2016 / Published online: 10 February 2016

(C) The Author(s) 2016. This article is published with open access at Springerlink.com

\begin{abstract}
Lactic acid bacteria (LAB) constitute a heterogeneous group of microorganisms that produce lactic acid as the major product during the fermentation process. LAB are Gram-positive bacteria with great biotechnological potential in the food industry. They can produce bacteriocins, which are proteinaceous antimicrobial molecules with a diverse genetic origin, posttranslationally modified or not, that can help the producer organism to outcompete other bacterial species. In this review, we focus on the various types of bacteriocins that can be found in $L A B$ and the organization and regulation of the gene clusters responsible for their production and biosynthesis, and consider the food applications of the prototype bacteriocins from LAB. Furthermore, we propose a revised classification of bacteriocins that can accommodate the increasing number of classes reported over the last years.
\end{abstract}

Electronic supplementary material The online version of this article (doi:10.1007/s00253-016-7343-9) contains supplementary material, which is available to authorized users.

Oscar P. Kuipers

o.p.kuipers@rug.nl

1 Department of Molecular Genetics, Groningen Biomolecular Sciences and Biotechnology Institute, University of Groningen, Nijenborgh 7, 9747 AG Groningen, The Netherlands

2 Present address: Department of Biochemistry, Groningen Biomolecular Sciences and Biotechnology Institute and Zernike Institute for Advanced Materials, University of Groningen, Nijenborgh 4, 9747 AG Groningen, The Netherlands

3 School of Biotechnology and Food Engineering, Hefei University of Technology, Hefei 230009, China
Keywords Bacteriocin - Lactic acid bacteria $\cdot$ Antimicrobial peptides $\cdot$ Lantibiotics $\cdot$ Lasso peptides $\cdot$ Sactipeptides . Circular bacteriocin $\cdot$ Linear azole-containing peptides . Glycocins

\section{Introduction}

The production of antagonistic substances by living organisms is a conserved characteristic throughout evolution, constituting an effective ancestral defense mechanism. Bacteriocins are ribosomally produced antimicrobial peptides from bacteria, either processed or not by additional posttranslational modification (PTM) enzymes, and exported to the extracellular medium (Cotter et al. 2005).

Bacteriocins produced by lactic acid bacteria (LAB) are particularly interesting due to the long history of safe use of some of them and the generally regarded as safe (GRAS) and Qualified Presumption of Safety (QPS) status that most LAB possess. LAB are a heterogeneous group of Gram-positive fermentative bacteria belonging to Firmicutes that encompasses various genera (Table 1) (Carr et al. 2002). Although bifidobacteria are not strictly LAB, they have been traditionally studied together and will also be considered in this review.

We aim to provide an overview of the prevalence of bacteriocin classes in $\mathrm{LAB}$. We highlight the classes that have been described in LAB providing examples of the most relevant cases for each class paying attention to the genetics, structure, and mechanism of action. Moreover, we discuss some bacteriocin groups that can be detected in silico in publicly available LAB genomes even though no representative from a LAB has yet been reported. Due to their biotechnological interest, the application of some bacteriocins in food processing is briefly described. 
Table 1 Number of putative bacteriocin gene cluster identified in 238 complete genomes

\begin{tabular}{|c|c|c|c|c|c|c|c|c|c|c|}
\hline \multirow[t]{2}{*}{ Genera } & \multicolumn{7}{|l|}{ Class I } & \multirow[t]{2}{*}{ Class II } & \multirow[t]{2}{*}{ Class III } & \multirow[t]{2}{*}{ Total } \\
\hline & Lanthipeptide I & Lanthipeptide II & Cyclic peptide & Sactipeptide & Glycocin & Lasso peptide & LAP & & & \\
\hline Aerococcus (1) & & & & & & & & & & 0 \\
\hline Bifidobacterium (31) & & 2 & 2 & & & & & & & 4 \\
\hline Carnobacterium (3) & & 1 & 6 & & & & & 1 & & 8 \\
\hline Enterococcus (12) & & 3 & & 1 & 1 & & & 13 & 7 & 25 \\
\hline Lactobacillus (59) & & & 16 & & 23 & & 3 & 86 & 76 & 204 \\
\hline Lactococcus (13) & 3 & & & 7 & & & 1 & 20 & 1 & 32 \\
\hline Leuconostoc (8) & & & 1 & & & & & 6 & & 7 \\
\hline Oenococcus (1) & & & 1 & & & & & & & 1 \\
\hline Pediococcus (3) & 1 & & & & & & & & 2 & 3 \\
\hline Streptococcus (105) & 16 & 22 & 15 & 7 & 5 & 4 & 33 & 388 & 10 & 500 \\
\hline Tetragenococcus (1) & & & & & & & & & 1 & 1 \\
\hline Weisella $(1)$ & & & & & & & & & & 0 \\
\hline TOTAL & 19 & 29 & 41 & 15 & 29 & 4 & 37 & 514 & 97 & 785 \\
\hline
\end{tabular}

Numbers in parentheses () indicate the number of genomes analyzed per genus

\section{Classification of bacteriocins from lactic acid bacteria}

There are a large number of bacteriocins isolated from nature. Some databases have been created to compile this information (e.g., van Heel et al. 2013). In addition to published bacteriocins, the repertoire of molecules hidden in the genomes that have not been isolated yet represents a valuable source of novel compounds with great potential. Diverse tools have been created that can be used for the automated screening of bacteriocin gene clusters (Blin et al. 2013; van Heel et al. 2013). A total of 238 complete LAB genomes deposited in public databases and belonging to the genera indicated in Table 1 were analyzed using Bagel3. This search resulted in a list of 785 putative bacteriocin gene clusters, including ribosomally produced and posttranslationally modified peptides (RiPPs) that were not previously identified in LAB. In this list, we could observe previously characterized bacteriocins or natural variants, some of them spread among different species, and new putative bacteriocins with no significant homology to known peptides based on the blast results provided (Table S1).

Since the first classification of LAB bacteriocins, proposed by Klaenhammer (1993), different schemes have been proposed taking it as a basis. New RiPP subgroups with antimicrobial activity produced by bacteria have been discovered that do not fit in either classification in spite of fitting in the definition of bacteriocin. We propose a slightly adjusted classification for LAB that can accommodate the novel subclasses that are appearing, based on the biosynthesis mechanism and biological activity, which is in acoordance with previous proposals (Cotter et al. 2013; Arnison 2013). Although we focus on bacteriocins from $\mathrm{LAB}$, this scheme is also valid for known compounds from other microorganisms (Fig. 1).
Class I: RiPPs (less than $10 \mathrm{kDa}$ ) This class encompasses all the peptides that undergo enzymatic modification during biosynthesis, which provides molecules with uncommon amino acids and structures that have an impact on their properties (e.g., lanthionine, heterocycles, head-to-tail cyclization, glycosylation). They consist of a leader peptide which serves for enzyme recognition, transport, and keeping the peptide inactive, which is fused to a core peptide (Arnison et al. 2013). The key signatures for an appropriate and systematic definition of novel members of this class have been recently suggested (Medema et al. 2015). Other RiPP subclasses not found in $\mathrm{LAB}$ are not further discussed here (for a review see Arnison et al. 2013).

Class II: unmodified bacteriocins (less than $10 \mathrm{kDa}$ ) This class groups bacteriocins that do not contain unusual modifications. Thus, they do not require enzymes for their maturation other than a leader peptidase and/or a transporter.

Class III These are unmodified bacteriocins larger than $10 \mathrm{kDa}$ with bacteriolytic or non-lytic mechanism of action.

\section{Class I: small posttranslationally modified peptides}

\section{Class Ia. Or lanthipeptides (types I, II, III, and IV)}

Lanthipeptides are peptides possessing unusual amino acids, such as lanthionine and/or (methyl)lanthionine (Arnison et al. 2013). Lanthipeptides undergo PTMs, and generally the genes involved in the maturation process are located in the same operon. Based on the PTM enzymes involved in the maturation process, lanthipeptides can be divided into four types, but 
Fig. 1 Proposed classification scheme for bacteriocins and their structures. Classes identified in silico are depicted in gray. Structure of non-lytic bacteriocins of class III still remains uncharacterized. *Bacteriocins from non-lactic acid bacteria

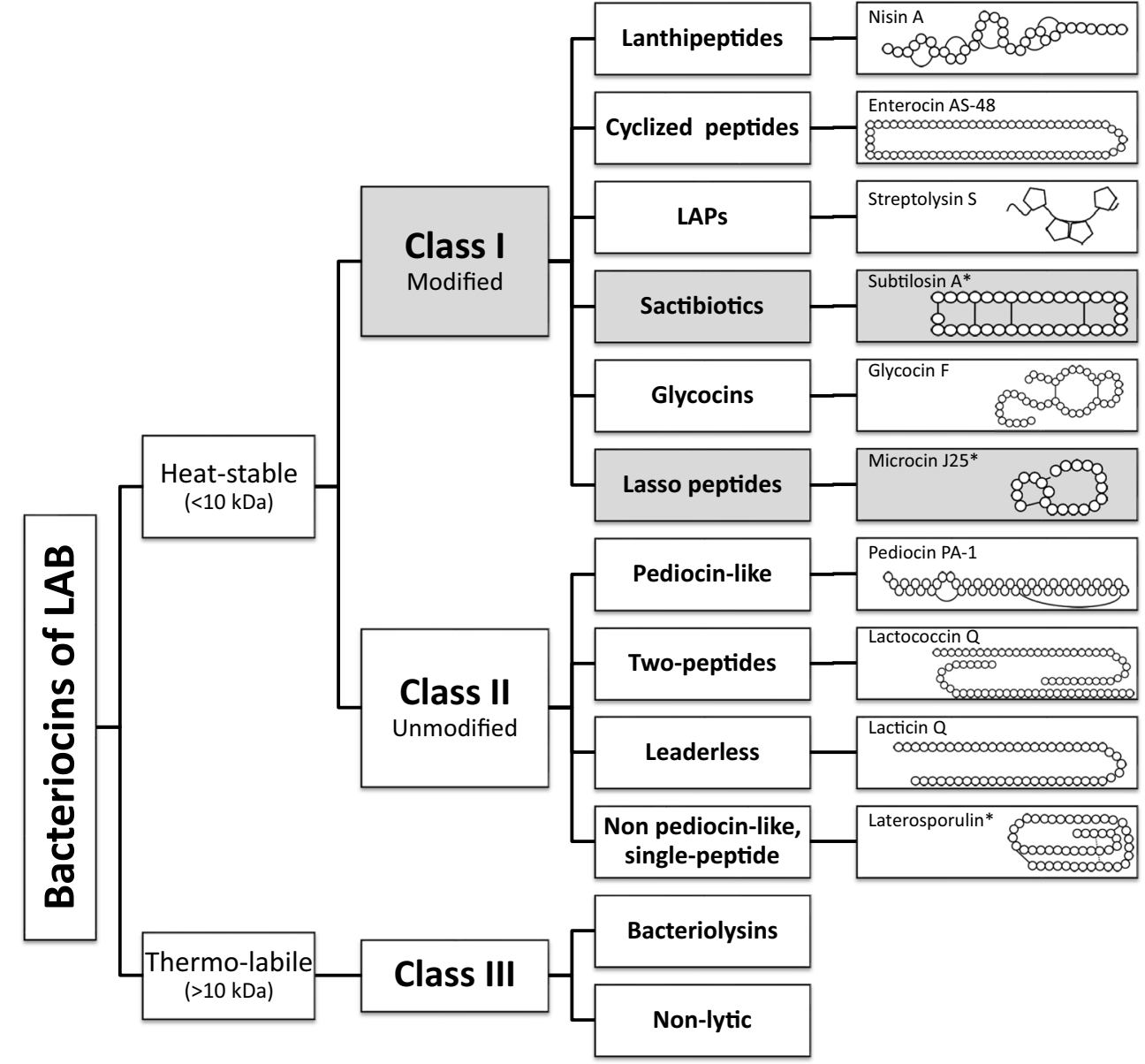

only types I (LanBC-modified) and II (LanM-modified) can be considered lantibiotics (Knerr and van der Donk 2012). Types III and IV have no known antimicrobial activity and are not further considered here.

A great number of different lantibiotics are produced by LAB (Table 1). Among them, nisin, a type I lantibiotic produced by Lactococcus lactis, is the best studied. The nisin biosynthetic gene cluster consists of 11 genes (Fig. 2). Promoters transcribing the nisABTCIP (biosynthesis and immunity) and nisFEG (immunity) operons are controlled by the two-component system NisRK that responds to the nisin concentration in a typical quorum sensing (QS) system (Lubelski et al. 2008). This QS mechanism has been also shown for type II lantibiotics such as bovicin HJ50 (Ni et al. 2011).

Lantibiotic maturation is a process encompassing several enzymatic reactions. The nisin precursor is modified by the dehydratase NisB which dehydrates Ser and Thr via glutamyl-tRNA-dependent glutamylation and elimination (Garg et al. 2013; Ortega et al. 2015). The cyclase NisC promotes the reversible Michael-type nucleophilic attack from the thiol group of a cysteine to an N-terminallocated dehydrated residue rendering the (methyl)lanthionine rings (Lubelski et al. 2008; Yang and van der Donk 2015). Subsequently, the fully modified precursor is transported (NisT) and proteolytically activated (NisP) (Lubelski et al. 2008). For some type I lantibiotics, this step is performed most likely intracellularly (e.g., Pep5) or even by an unknown leader peptidase not associated to the lantibiotic cluster (e.g., subtilin) (Knerr and van der Donk 2012). In type II lantibiotics, the processes of dehydration and cyclization are carried out by a bifunctional LanM enzyme that performs the phosphorylationelimination reaction on the dehydratable residues and forms the rings (Knerr and van der Donk 2012). Lacticin 3147 from L. lactis is one of the best-studied type II lantibiotics. It consists of two peptides, LtnA 1 and LtnA2, which are processed by LtnM1 and LtnM2, respectively. Finally, the bifunctional enzyme LtnT removes the leader peptide and translocates the modified peptides (Suda et al. 2012). Recently, the role of the leader peptide of lantibiotics as an activator of the PTM enzymes has been revealed (Oman et al. 2012). Apart from lanthionine rings and dehydrated residues, other modified amino acids have been detected in lantibiotics (Knerr and van der Donk 2012; Ortega et al. 2014; Lohans et al. 2014). 
Fig. 2 Schematic representation of bacteriocin gene clusters (not drawn to scale). Black, structural genes; dark gray, transporter genes; light gray, modification and maturation genes; bars, immunity genes; white, others. *Bacteriocins from non-lactic acid bacteria

\section{CLASS I}

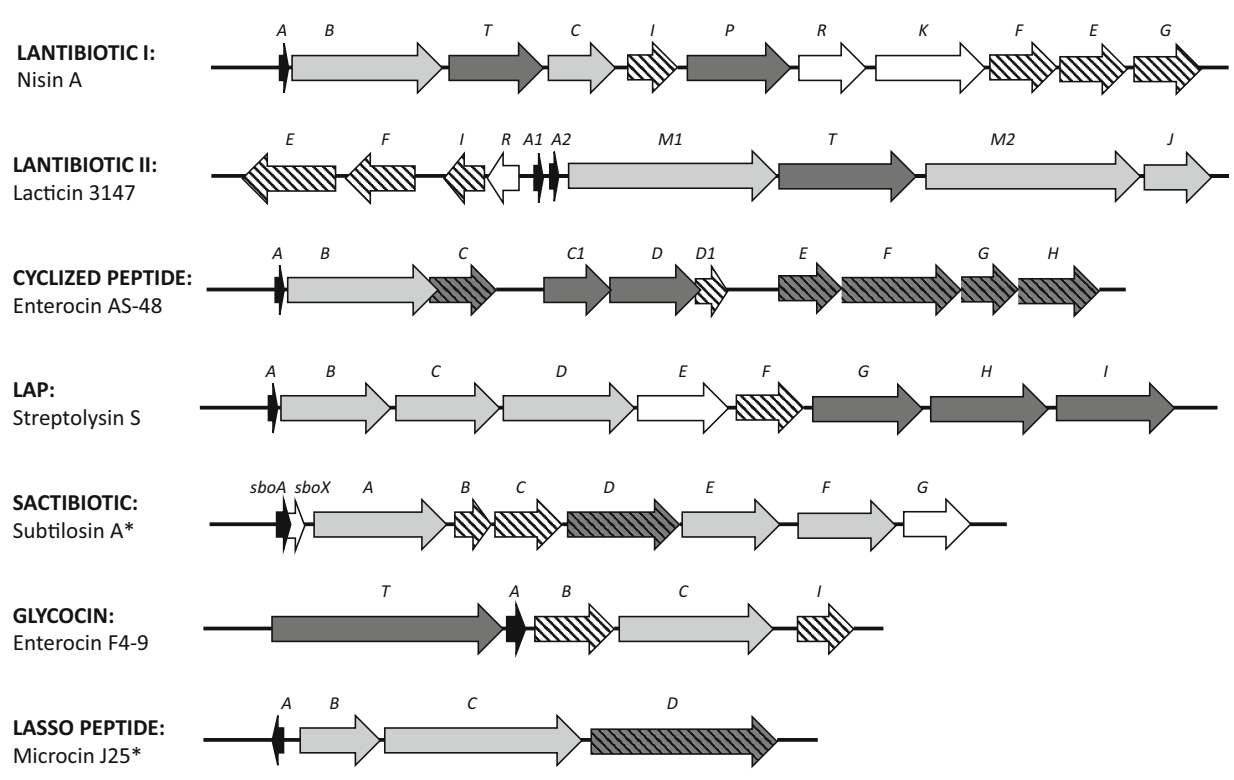

\section{CLASS II}

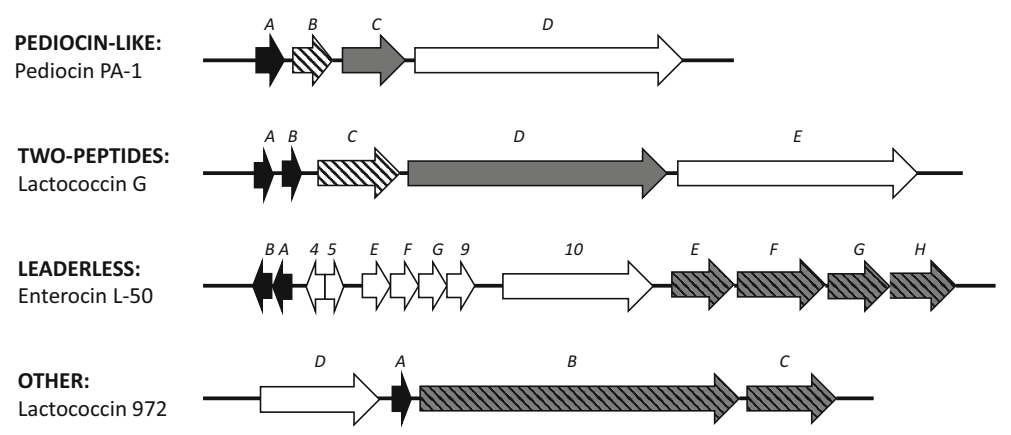

\section{CLASS III}

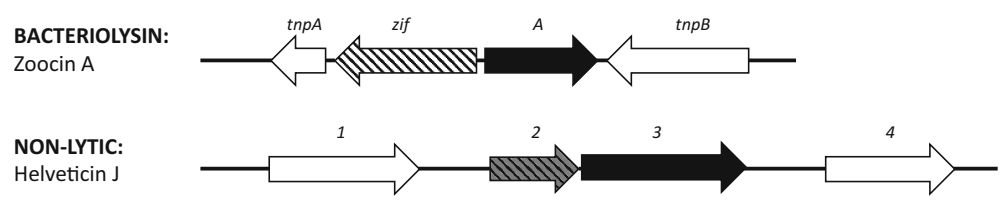

The mechanism of action of most lantibiotics relies on lipid II binding. Nisin inhibits its target removing lipid II from its natural location and subsequent insertion into the cell membrane to form a pore (Breukink et al. 1999; Hasper et al. 2006; Lubelski et al. 2008). Lacticin 3147 also targets lipid II, and a three-step model has been proposed where the $\alpha$-peptide binds to lipid II, then it is recognized by the $\beta$-peptide which inserts into the membrane and forms a pore (Wiedeman et al. 2006; Suda et al. 2012). It has been reported that other type II lantibiotics lack the ability to form pores after interaction with lipid II via a specific binding pocket (Islam et al. 2012), but can strongly induce a cell stress response (Sass et al. 2008). The poreforming ability of some lantibiotics is compromised by the membrane composition and thickness of the sensitive strain (Wiedeman et al. 2006). 


\section{Class Ib. Or head-to-tail cyclized peptides}

Head-to-tail cyclized bacteriocins are a group of RiPPs whose $\mathrm{N}$ - and $\mathrm{C}$-termini are linked by a peptide bond, thereby rendering a circular molecule (Fig. 1). All of them contain only alpha helical segments (either 4 or 5) and share a similar structure with a saposin folding (Montalbán-López et al. 2012a; Lohans et al. 2013; Acedo et al. 2015; Himeno et al. 2015).

In spite of their similar structure, two different mechanisms of action are shown for circular bacteriocins, both involving pore formation. In the case of carnocyclin A, it is able to form pores in bacterial membranes in a voltage-dependent manner (Gong et al. 2009). Multimers of carnocyclin A are not found in solution (Martin-Visscher et al. 2009). On the other hand, AS-48 forms dimers in aqueous solution which rearrange in the membrane to bury the hydrophobic core in the lipid bilayer (Cruz et al. 2013; Cebrián et al. 2015). Studies with garvicin ML show that the expression of a maltose-binding protein in L. lactis increases the sensitivity to this bacteriocin (Gabrielsen et al. 2012). This constitutes the first report on a putative target for a circular bacteriocin, although its exact role remains to be demonstrated.

The gene cluster of AS- 48 is formed by 10 genes including $a s-48 A$ which codes for the structural gene, $a s-48 B$ for a putative cyclase, $a s-48 C$ for a DUF95 protein related to immunity and production (Mu et al. 2014), as-48C1D for a putative $\mathrm{ABC}$ transporter related to production, $a s-48 D 1$ for a typical immunity protein, and $a s-48 E F G H$ for an additional $\mathrm{ABC}$ transporter which is immunity related (Fig. 2) (Maqueda et al. 2008). The minimal set for the functional expression of the circular bacteriocin circularin has been determined as cirABCDE (equivalent to as-48ABCDD1) (Maqueda et al. 2008). The transporter As-48EFGH is not present in some of the known gene clusters indicating that it has a minor role for production and it is related only to immunity (Maqueda et al. 2008; Gabrielsen et al. 2014a). No gene encoding for a putative regulator has been found in the $\mathrm{LAB}$ circular bacteriocins described, the only exception being a putative circular bacteriocin cluster detected in silico in Streptococcus pneumoniae that contains a putative regulator upstream the structural gene (Maqueda et al. 2008; Bogaardt et al. 2015). The expression of AS-48 requires the expression of a large transcript that encompasses $a s-48 A B C$ which is posttranscriptionally processed, a second transcript including as-48C1DD1EFGH, and a third transcript from a weak promoter that transcribes as48D1EFGH (Sánchez-Hidalgo et al. 2011; Cebrián et al. 2014). The typical organization, where the expression of the structural gene is paired to the expression of the immunity and the maturation machinery, is not present in the garvicin ML gene cluster (Gabrielsen et al. 2014b).

The fact that there is not a C-terminal extension in circular bacteriocins as in the case of cyclotides or cyanobactins and that the leader peptide seems to be cleaved off in a separate step could indicate that the cyclization takes place during transport involving the ATPase activity to provide the energy necessary for the peptide bond formation (Montalbán-López et al. 2012a; Craik and Malik 2013; Gabrielsen et al. 2014a; Scholz et al. 2014).

\section{Class Ic. Or sactibiotics}

Sactipeptides (also referred to as sactibiotics when they possess antimicrobial activity) are sulphur-to- $\alpha$-carboncontaining peptides (Arnison et al. 2013; Mathur et al. 2015). To the best of our knowledge, there has been no sactipeptide from a LAB characterized so far and only putative clusters have been identified in silico (Table 1) (Table S1) (Murphy et al. 2011), awaiting further study.

They show great diversity, with the hairpin structure and the sulfur linkages being the common feature. The best studied, subtilosin A, is a negatively charged circular sactipeptide produced by Bacillus subtilis (Fig. 1) (Kawulka et al. 2003; Maqueda et al. 2008). It exhibits 3S-to- $\alpha$-carbon bonds and displays a broad spectrum activity against diverse bacteria (Montalbán-López et al. 2011; Mathur et al. 2015). Thuricin $\mathrm{CD}$ is a narrow-spectrum two-component linear sactibiotic produced by Bacillus thuringiensis with potent activity against Clostridium difficile (Rea et al. 2010). Thurincin H, also produced by $B$. thuringiensis, is a single peptide with 4Sto- $\alpha$-carbon bonds (Mathur et al. 2015).

No specific receptor has been identified for sactibiotics. The model, subtilosin A, can partly bury in the membrane of target cells, causing a disorder in the hydrophobic region of the membranes creating transient pores (Noll et al. 2011). On the other hand, thurincin $\mathrm{H}$ does not appear to affect the membrane permeability (Wang et al. 2014).

The common features in the sactibiotic gene clusters are the presence of the structural gene(s), immunity proteins, transporters, and S-adenosylmethionine enzymes containing a typical [4S-4Fe] conserved region (Fig. 2) (Flühe et al. 2013).

\section{Class Id. Or linear azol(in)e-containing peptides}

Linear azol(in)e-containing peptides (LAPs) are peptides possessing various combinations of heterocyclic rings of thiazole and (methyl)oxazole, which are derived from cysteine, serine, and threonine residues via ATP-dependent cyclodehydration and subsequent flavin mononucleotidedependent dehydrogenation (Melby et al. 2011). The most relevant LAB-produced LAP is streptolysin S (Fig. 1) (Cox et al. 2015). Streptolysin S is modified by the cyclodehy dratase SagCD. Recently, the SagD-homolog YcaO was shown to be an ATP-dependent enzyme that phosphorylates the amide backbone, although the function of the SacC homolog was not clear (Dunbar et al. 2012). Often, the SagCD 
analogs in other gene clusters are fused as a single protein. Additionally, the synthesis of streptolysin $\mathrm{S}$ requires the dehydrogenase $\mathrm{SagB}$, the protease $\mathrm{SagE}$, the $\mathrm{ABC}$ transporter SagGHI, and SagF, probably related with immunity (Lee et al. 2008). The whole set cluster is controlled by a single promoter with a rho-independent terminator behind the structural gene sagA (Fig. 2) (Nizet et al. 2000). Additional modifications have been found in other LAP clusters (Lee et al. 2008).

The mechanism of action of LAPs is unclear yet. Microcin B17, from Escherichia coli, can inhibit bacterial gyrase under certain conditions in a mechanism similar to quinolones (Heddle et al. 2001).

\section{Class Ie. Or glycocins}

Glycocins are bacteriocins containing glycosylated residue(s) (Arnison et al. 2013). Glycocin F from Lactobacillus plantarum was the first glycocin described in LAB (Stepper et al. 2011). Glycocin F is arranged as two alpha helices held together by disulfide bonds (Venugopal et al. 2011). It possesses an $\mathrm{N}$-acetylglucosamine $\beta$-O-linked to serine and an $\mathrm{N}$ acetylhexosamine $\mathrm{S}$-linked to the $\mathrm{C}$-terminal cysteine, a very infrequent type of glycosylation (Stepper et al. 2011). Little is known about the mechanism of action of glycocins. The Olinked $\mathrm{N}$-acetylglucosamine could interact reversibly with target cells (Stepper et al. 2011). Apart from glycocin F, enterocin F4-9 from Enterococcus faecium has also been described (Fig. 1) (Maky et al. 2015). The biosynthetic gene cluster of enterocin F4-9 consists of five genes (Fig. 2): enfT, a putative $\mathrm{ABC}$-transporter; the structural gene enfA49; the glycosyltransferase enfC; and enfB and enfI, which resemble a thioldisulfide isomerase and an immunity protein, respectively (Maky et al. 2015). Unlike glycocin F, enterocin F4-9 is assumed to be bacteriostatic (Maky et al. 2015).

\section{Class If. Or lasso peptides}

Lasso peptides are a group of RiPPs that show as a main characteristic the presence of an amide bond between the first amino acid in the core peptide chain and a negatively charged residue in positions +7 to +9 generating a ring that embraces the C-terminal linear part of the polypeptide (Fig. 1) (Arnison et al. 2013; Hegemann et al. 2015). Moreover, lasso peptides display diverse activities which range from antimicrobial to putative antiviral or anticancer (Maksimov et al. 2012). Additional modifications might be naturally present in lasso peptides (Hegemann et al. 2015). Up to date, no lasso peptide from $\mathrm{LAB}$ has been reported, but a few are predicted to occur in streptococci (Table 1) (Table S1).

The first antimicrobial lasso peptide characterized was microcin J25, produced by E. coli (Fig. 1). A cluster of four genes is required for the production of microcin J25, namely, the structural gene $m c j A$, the immunity determinant $m c j D$, the leader peptidase $m c j B$, and the cyclase $m c j C$ (Fig. 2) (Yan et al. 2012). Microcin J25 uses the siderophore transporter FhuA to enter the cell where it acts as a selective transcription inhibitor able to temporarily block the RNA elongation by the RNA polymerase (Mathavan et al. 2014). Additionally, microcin $\mathrm{J} 25$ induces the generation of reactive oxygen species that contribute to the inhibition mechanism (Chalon et al. 2009). Similarly, capistruin is a transcription inhibitor (Kuznedelov et al. 2011) whereas lassomycin is a protease inhibitor that targets Mycobacterium tuberculosis (Gavrish et al. 2014).

One of the main interests of lasso peptides is their use as peptide scaffolds due to their high stability. Diverse peptide sequences with additional functionalities or even unnatural amino acids can be displayed in lasso peptides (Piscotta et al. 2015; Hegemann et al. 2015).

\section{Class II: unmodified bacteriocins}

\section{Class IIa. Or pediocin-like bacteriocins}

The pediocin-like class IIa bacteriocins are broad spectrum antimicrobials particularly active agains Listeria (Kjos et al. 2011). The structure of peptides of class IIa can be divided in two different regions separated by a flexible hinge (Haugen et al. 2008). The cationic N-terminal half contains two cysteine residues joined by a disulfide bridge, and a conserved YGNGVXC motif, which has been suggested to participate in target interaction (Cui et al. 2012). The replacement of this disulfide bridge by hydrophobic interaction can still retain the activity (Sit et al. 2012). The $\mathrm{C}$-terminus is less conserved and seems to be involved in the target cell specificity (Cui et al. 2012).

Class IIa bacteriocins are subdivided into eight groups on the basis of their primary structures (Nissen-Meyer et al. 2009). However, the first and the most extensively studied representative of this class is pediocin PA-1. The gene cluster of pediocin PA-1, like most IIa bacteriocins, is plasmid encoded (Ennahar et al. 1999). The pediocin PA-1 operon contains four genes, namely, the structural gene pedA; the immunity determinant pedB; and pedC and pedD which encode an $\mathrm{ABC}$ transporter and the accessory protein (Fig. 2). The operon produces two different transcripts; the smaller and most abundant corresponds to the pedABC genes, while the second transcript is larger and covers pedABCD (Nissen-Meyer et al. 2009; Cui et al. 2012). The leader peptide serves as a recognition signal for the processing and the secretion of the bacteriocin by a dedicated $\mathrm{ABC}$ transporter. In a few cases, the bacteriocin is secreted by the sec-dependent translocation system (De Kwaadsteniet et al. 2006). Class IIa bacteriocins can be constitutively produced 
(e.g., pediocin PA-1) or regulated by a QS system (e.g., sakacin A) (Ennahar et al. 1999).

The mode of action of class IIa bacteriocins comprises three basic steps: pediocin binds to the sugar transporter mannose phosphotransferase system (Man-PTS) receptors, inserts into the cytoplasmic membrane, and finally forms the pore complex (Diep et al. 2007).

\section{Class IIb. Or two-peptide bacteriocins}

Class IIb bacteriocins consist of two very different peptides, and full activity requires the presence of both peptides in about equal quantities (Nissen-Meyer et al. 2010). In some cases, such as lactococcin $\mathrm{G}$ from L. lactis (Nissen-Meyer et al. 1992), antimicrobial activity requires the presence of both peptides. However, for others such as thermophilin 13 from Streptococcus thermophilus (Marciset et al. 1997), individual peptides manifest antimicrobial activity by themselves, although their combination always increases the activity. Exceptionally in enterocin X, this varies in function of the indicator strain $(\mathrm{Hu}$ et al. 2010). The peptides can be combined with a complementary peptide from a homologous two-peptide bacteriocin (Oppegård et al. 2007).

Mode-of-action studies of lactococcin G propose that the peptides form a membrane-penetrating helix-helix structure that interacts with a receptor of the membrane of sensitive bacteria (Rogne et al. 2008), causing membrane leakage. Lactococcin G-resistant mutants produced in the lab pointed at the UppP protein, a membrane protein involved in peptidoglycan synthesis, as the putative receptor for lactococcin $\mathrm{G}$ and enterocin 1071 (Kjos et al. 2014).

The class IIb bacteriocin production requires at least five different genes, and they might be organized in either one or two different operons. Lactococcin $\mathrm{G}$ contains two structural genes codifying the pre-bacteriocins, an immunity gene, a gene that encodes a dedicated ABC transporter, and a gene encoding an accessory protein whose function is still unclear; all of them are arranged in the same operon (Fig. 2) (Oppegård et al. 2010). The structural genes are always produced in equal quantities and found next to each other in the same operon along with only one immunity gene. This fact suggests that the peptides work together as one unit (Nissen-Meyer et al. 2009; Rogne et al. 2008). The production of class IIb bacteriocins is transcriptionally regulated by a QS system of three components, which involves an induction factor, a membraneassociate protein histidine kinase, and response regulators. Plantaricin A, for instance, is the inductor factor of two two-peptide bacteriocins, plantaricin $\mathrm{J} / \mathrm{K}$ and plantaricin E/F, from L. plantarum C11 (Diep et al. 2003).

\section{Class IIc. Or leaderless bacteriocins}

Leaderless bacteriocins are unique as they are synthetized without an N-terminal leader peptide, which usually functions as a recognition sequence for secretion and modification and maintains the bacteriocin inactive inside the producer cell (Liu et al. 2011; Masuda et al. 2012).

One of the best studied and characterized leaderless bacteriocins is the plasmid-encoded two-peptide enterocin L50 from E. faecium L50 (Fig. 1) (Cintas et al. 1998). The gene cluster of enterocin L50 encodes 13 open reading frame (ORF) (Fig. 2), including the two structural genes in tandem, some accessory proteins, and four genes highly homologous to the second $\mathrm{ABC}$ transporter as-48EFGH, which participates in immunity (Franz et al. 2007). The lack of genes encoding immunity proteins is a common feature among leaderless bacteriocins, and the self-immunity mechanism is therefore still unclear (Iwatani et al. 2012).

NMR research has shown that enterocins $7 \mathrm{~A}$ and $7 \mathrm{~B}$ are highly homologous to enterocins L50A and L50B and, unlike most linear bacteriocins such as EJ97 (Neira et al. 2010), maintain a defined structure in aqueous conditions (Lohans et al. 2013). Moreover, enterocins 7A and 7B share a structural motif with the circular bacteriocins. Lacticin Q causes membrane leakage without any specific membrane receptor (Yoneyama et al. 2009a). Cationic lacticin Q binds to negatively charged membranes by electrostatic interactions and forms huge toroidal pores that cause leakage (Yoneyama et al. 2009b). In spite of the lack of a docking molecule, the mechanism is selective against several sensitive Grampositive bacteria due to accumulation of hydroxyl radicals as activity-inducing factor ( $\mathrm{Li}$ et al. 2013). On the contrary, a zincdependent membrane metallopeptidase has been identified as the docking molecule of the leaderless bacteriocin LsbB from L. lactis subsp. lactis BGMN1-5 (Uzelac et al. 2013). Recently, it has been described for the first time that the expression of LsbB is regulated by a transcription terminator sequence located downstream of the structural gen (Uzelac et al. 2015).

\section{Class IId. Or non-pediocin-like, single-peptide bacteriocins}

Class IId is a heterogeneous group of unrelated single linear peptide bacteriocins with different structures, mechanisms of secretion, and manners of action such as lactococcin 972, lactococcin A, and enterocin B (Franz et al. 2007).

Lactococcin 972 is a heat-sensitive $\mathrm{pH}$-stable peptide active against closely related lactococci species (Martínez et al. 1999). The NMR structure of lactococcin 972 has been recently determined (Turner et al. 2012). The gene cluster is located in a plasmid and comprises the structural gene $l c n 972$ and two hypothetical genes which could encode a dedicated ABC transporter involved in immunity (Fig. 2) (Campelo et al. 
2014). The mature protein is secreted via a sec-dependent system. Two different transcripts are produced: one comprises the whole operon, and the second corresponds to the structural gene (Martínez et al. 1999). The mechanism of action in lactococcin 972 is through the inhibition of the cell wall biosynthesis in lactococci by binding to the cell wall precursor lipid II (Martínez et al. 2000).

Lactococcin A is a narrow spectrum bacteriocin produced by strains of L. lactis (Holo et al. 1991). The biosynthesis of lactococcin A involves four different genes: the structural gene $(l c n A)$, the immunity gene $(l c i A)$, and two genes $(l c n C$, $l c n D$ ) that encode the dedicated $\mathrm{ABC}$ transporter system and its accessory protein (Stoddard et al. 1992). The Man-PTS is the target receptor of lactococcin A (Diep et al. 2007).

\section{Class III}

Class III bacteriocins are large-molecular-weight and heatlabile antimicrobial proteins usually composed of different domains. For instance, based on sequence analysis, enterolysin A consists of an $\mathrm{N}$-terminal endopeptidase domain and a C-terminal substrate recognition domain similarly to zoocin A (Nilsen et al. 2003; Lai et al. 2002). Zoocin A, a D-alanyl-L-alanine endopeptidase, is one of the bestcharacterized LAB bacteriolysins (Fig. 2) (Simmonds et al. 1996). It shows antimicrobial activity against other streptococci by cleaving the peptidoglycan cross-links of the target cell wall (Simmonds et al. 1996). The zif gene, close to $z o o A$, encodes an immunity protein which adds L-alanine into the peptidoglycan cross-bridges, thus decreasing the ability of zoocin A to degrade the peptidoglycan layer (Gargis et al. 2009).

Millericin B is a murein hydrolase. Its production depends on the expression of three genes encoding millericin $\mathrm{B}$ precursor (MilB), immunity protein (MilF), and transporter protein (MilT) (Beukes et al. 2000). Similarly, enterolysin A cleaves within the peptidoglycan of target cells between Lalanine and D-glutamic acid of the stem peptide and between L-lysine of the stem peptide and D-aspartic acid of the interpeptide bridge (Khan et al. 2013).

On the other hand, non-lytic bacteriocins exhibit their bactericidal mode without causing concomitant cell lysis. For instance, dysgalacticin from $S$. pyogenes binds to the glucose- and/or Man-PTS, resulting in the inhibition of the sugar uptake, and also causes a membrane leakage of small molecules (Swe et al. 2009). In contrast, caseicin from Lactobacillus casei inhibits the biosynthesis of DNA and proteins of target bacteria (Müller and Radler 1993). Little is known about their genetics. The biosynthesis of helveticin J from Lactobacillus helveticus 481 involves at least three ORF, but their specific functions remain still unknown (Fig. 2) (Joerger and Klaenhammer 1990).

\section{Application in the food industry}

Nowadays, consumers ask for safe, healthy, tasting, long shelf-life, and minimally processed food products. LAB are food-grade microorganisms that have been extensively used in fermented foods, and many of them have GRAS and QPS status. As a result, bacteriocins and other metabolites produced by LAB are also generally considered as safe compounds with interesting properties (e.g., stability, antimicrobial activity, lack of toxicity, no flavor alteration) (Carr et al. 2002; Cotter et al. 2005). Until now, only nisin and pediocin PA-1 have been commercialized as food additives. However, other LAB bacteriocins also offer promising perspectives to be used as biopreservatives in food, like for instance the enterocin AS-48 (Sánchez-Hidalgo et al. 2011) or lacticin 3147 (Suda et al. 2012).

Bacteriocins can be added as bacteriocin preparations or by direct inoculation of the bacteriocin-producing strain. The bacteriocin preparation can be a purified or semi-purified bacteriocin added as food preservative, such as nisin which is commonly exploited under the name of Nisaplin ${ }^{\mathrm{TM}}$ (Danisco, E234) (Cotter et al. 2005). In fact, nisin is the only bacteriocin licensed as biopreservative in over 50 countries. Bacteriocins can also be added in the form of concentrated fermentate generated from a bacteriocin-producing strain. For instance, ALTA $2431^{\mathrm{TM}}$ (Quest) is a fermentation product from a pediocin PA-1-producing strain (Rodríguez et al. 2002). Bacteriocinogenic strains can be as well directly inoculated into the food as starter, adjunct, or protective cultures. Actually, LAB and, therefore, their bacteriocins, have been empirically applied as starter cultures in the production of traditional foods (Leroy et al. 2006; Alegría et al. 2010). Recently, bacteriocins have also been incorporated into packaging films to control food-borne pathogenic bacteria ensuring a gradual release of bacteriocins into the food and avoiding the inactivation of the bacteriocin by interaction with food components (Guerra et al. 2005). Furthermore, several studies have shown that bacteriocin antimicrobial activity is enhanced against Gram-negative bacteria when combined with physicochemical treatments (hurdle technology) such as high pressure (Pérez Pulido et al. 2015), organic acids (Ukuku and Fett 2004), phenolic compounds (Grande et al. 2007), and pulsed electric fields (Martínez Viedma et al. 2008).

\section{Enhancement of probiotic action}

Many LAB strains are proposed as probiotics, i.e., live microorganisms which, when administered in adequate amounts, confer a health benefit on the host (FAO/WHO 2001). In recent years, several in vitro and in vivo studies have shown that LAB bacteriocins exhibit a protective effect in the gastrointestinal tract (GIT) by excluding pathogens or promoting gut colonization (Corr et al. 2007; Dobson et al. 2012; 
Kommineni et al. 2015). For instance, the antilisterial Abp118 from Lactobacillus salivarius UCC118 protects mice against infection with the pathogen L. monocytogenes (Corr et al. 2007), and the $S$. mutans BCS3-L1 strain is able to replace existing $S$. mutans populations and persist over time in the oral cavity, due to the advantage conferred by its bacteriocin, mutacin 1140 (Hillman et al. 2000). Furthermore, Kominneni et al. (2015) proved that niche competition in the GIT is directly influenced by bacteriocin expression by commensal bacteria.

Gastrointestinal infections are a major concern in human health, but antibiotics cause a harmful effect on gut microbiota. Therefore, the anti-infective effect of LAB-producing bacteriocins is a promising alternative to antibiotics, especially for particular cases where other methods are not allowed (e.g., pregnant women) (Hammami et al. 2013).

\section{Concluding remarks}

The concomitant application of bacteriocin-producer LAB or (semi)purified bacteriocins, together with the application of other physicochemical treatments, constitutes an effective method of natural biopreservation in food industry and enables the reduction of other costly or user-unfriendly treatments, while increasing the product self-life.

The discovery of the gene clusters encoding for RiPPs that were previously thought to be non-ribosomally produced but assembled by multimeric enzymatic complexes demonstrates the huge chemical diversity that can be achieved in natural products by the sequential modification of a peptide substrate by specific PTMs. This chemical diversity is related to different properties (i.e., antimicrobial spectrum, stability, potency). The conserved motifs in the PTMs and the core peptides facilitate the highthroughput analysis of (meta)genomic data which can help focus the screening efforts to discover new molecules using diverse alternatives (Montalbán-López et al. 2012b; Hegemann et al. 2015; Rutledge and Challis 2015). In addition to the three bacteriocin classes proposed in the early 1990s (Klaenhammer 1993), our broad genome mining analysis of LAB shows that the repertoire of antimicrobials that are encoded in public sequences could be even broader than expected, with some putative classes not reported so far in LAB (i.e., lasso peptides and sactipeptides), opening up a wide range of possibilities for future applications.

Acknowledgments We thank Dr. Anne de Jong for his help with genome mining using Bagel 3.

Compliance with ethical standards This article does not contain any studies with human participants or animals performed by any of the authors.
Funding D. Mu was supported by the China Scholarship Council (no. 2010605032). M. Montalbán-López was supported by the EU FP7 project SynPeptide.

Conflict of interest The authors declare that they have no competing interest.

Open Access This article is distributed under the terms of the Creative Commons Attribution 4.0 International License (http:// creativecommons.org/licenses/by/4.0/), which permits unrestricted use, distribution, and reproduction in any medium, provided you give appropriate credit to the original author(s) and the source, provide a link to the Creative Commons license, and indicate if changes were made.

\section{References}

Acedo JZ, van Belkum MJ, Lohans CT, McKay RT, Miskolzie M, Vederas JC (2015) Solution structure of acidocin B, a circular bacteriocin produced by Lactobacillus acidophilus M46. Appl Environ Microbiol 81:2910-2918. doi:10.1128/AEM.04265-14

Alegría A, Delgado S, Roces C, López B, Mayo B (2010) Bacteriocins produced by wild Lactococcus lactis strains isolated from traditional, starter-free cheeses made of raw milk. Int J Food Microbiol 143: 61-66. doi:10.1016/j.ijfoodmicro.2010.07.029

Arnison PG, Bibb MJ, Bierbaum G, Bowers AA, Bugni TS, Bulaj G, Camarero JA, Campopiano DJ, Challis GL, Clardy J, Cotter PD, Craik DJ, Dawson M, Dittmann E, Donadio S, Dorrestein PC, Entian K-D, Fischbach MA, Garavelli JS, Göransson U, Gruber CW, Haft DH, Hemscheidt TK, Hertweck C, Hill C, Horswill AR, Jaspars M, Kelly WL, Klinman JP, Kuipers OP, Link AJ, Liu W, Marahiel MA, Mitchell DA, Moll GN, Moore BS, Müller R, Nair SK, Nes IF, Norris GE, Olivera BM, Onaka H, Patchett ML, Piel J, Reaney MJT, Rebuffat S, Ross RP, Sahl H-G, Schmidt EW, Selsted ME, Severinov K, Shen B, Sivonen K, Smith L, Stein T, Süssmuth RD, Tagg JR, Tang G-L, Truman AW, Vederas JC, Walsh CT, Walton JD, Wenzel SC, Willey JM, van der Donk WA (2013) Ribosomally synthesized and post-translationally modified peptide natural products: overview and recommendations for a universal nomenclature. Nat Prod Rep 30:108-160. doi:10.1039/c2np20085f

Beukes M, Bierbaum G, Sahl HG, Hastings JW (2000) Purification and partial characterization of a murein hydrolase, millericin B, produced by Streptococcus milleri NMSCC 061. Appl Environ Microbiol 66:23-28. doi:10.1128/AEM.66.1.23-28.2000

Blin K, Medema MH, Kazempour D, Fischbach MA, Breitling R, Takano E, Weber T (2013) AntiSMASH 2.0 - a versatile platform for genome mining of secondary metabolite producers. Nucleic Acids Res 41:W204-W212. doi:10.1093/nar/gkt449

Bogaardt C, van Tonder AJ, Brueggemann AB (2015) Genomic analyses of pneumococci reveal a wide diversity of bacteriocins - including pneumocyclicin, a novel circular bacteriocin. BMC Genomics 16: 554. doi:10.1186/s12864-015-1729-4

Breukink E, Wiedemann I, van Kraaij C, Kuipers OP, Sahl HG, de Kruijff B (1999) Use of the cell wall precursor lipid II by a pore-forming peptide antibiotic. Science 286:2361-2364. doi:10.1126/science. 286.5448.2361

Campelo AB, Roces C, Mohedano ML, López P, Rodríguez A, Martínez B (2014) A bacteriocin gene cluster able to enhance plasmid maintenance in Lactococcus lactis. Microb Cell Factories 13:77. doi:10. 1186/1475-2859-13-77

Carr FJ, Chill D, Maida N (2002) The lactic acid bacteria: a literature survey. Crit Rev Microbiol 28:281-370. doi:10.1080/1040840291046759 
Cebrián R, Rodríguez-Ruano S, Martínez-Bueno M, Valdivia E, Maqueda M, Montalbán-López M (2014) Analysis of the promoters involved in enterocin AS-48 expression. PLoS One 9:e90603. doi: 10.1371/journal.pone.0090603

Cebrián R, Martínez-Bueno M, Valdivia E, Albert A, Maqueda M, Sánchez-Barrena MJ (2015) The bacteriocin AS-48 requires dimer dissociation followed by hydrophobic interactions with the membrane for antibacterial activity. J Struct Biol 190:162-172. doi:10. 1016/j.jsb.2015.03.006

Chalon MC, Bellomio A, Solbiati JO, Morero RD, Farias RN, Vincent PA (2009) Tyrosine 9 is the key amino acid in microcin J25 superoxide overproduction. FEMS Microbiol Lett 300:90-96. doi:10.1111/j. 1574-6968.2009.01770.x

Cintas LM, Casaus P, Holo H, Hernandez PE, Nes IF, Håvarstein LS (1998) Enterocins L50A and L50B, two novel bacteriocins from Enterococcus faecium L50, are related to staphylococcal hemolysins. J Bacteriol 180:1988-1994

Corr SC, Li Y, Riedel CU, O'Toole PW, Hill C, Gahan CG (2007) Bacteriocin production as a mechanism for the antiinfective activity of Lactobacillus salivarius UCC118. Proc Natl Acad Sci U S A 104: 7617-7621. doi:10.1073/pnas.0700440104

Cotter PD, Hill C, Ross RP (2005) Bacteriocins: developing innate immunity for food. Nat Rev Microbiol 3:777-788. doi:10.1038/ nrmicro 1273

Cotter PD, Ross RP, Hill C (2013) Bacteriocins - a viable alternative to antibiotics? Nat Rev Microbiol 11:95-105. doi:10.1038/ nrmicro2937

Cox CL, Doroghazi JR, Mitchell DA (2015) The genomic landscape of ribosomal peptides containing thiazole and oxazole heterocycles. BMC Genomics 16:778. doi:10.1186/s12864-015-2008-0

Craik DJ, Malik U (2013) Cyclotide biosynthesis. Curr Opin Chem Biol 17:546-554. doi:10.1016/j.cbpa.2013.05.033

Cruz VL, Ramos J, Melo MN, Martinez-Salazar J (2013) Bacteriocin AS48 binding to model membranes and pore formation as revealed by coarse-grained simulations. Biochim Biophys Acta 1828:25242531. doi:10.1016/j.bbamem.2013.05.036

Cui Y, Zhang C, Wang Y, Shi J, Zhang L, Ding Z, Qu X, Cui H (2012) Class IIa bacteriocins: diversity and new developments. Int J Mol Sci 13:16668-16707. doi:10.3390/ijms131216668

De Kwaadsteniet M, Fraser T, Van Reenen CA, Dicks LMT (2006) Bacteriocin T8, a novel class IIa sec-dependent bacteriocin produced by Enterococcus faecium T8, isolated from vaginal secretions of children infected with human immunodeficiency virus. Appl Environ Microbiol 72:4761-4766. doi:10.1128/AEM.00436-06

Diep DB, Myhre R, Johnsborg O, Aakra A, Nes IF (2003) Inducible bacteriocin production in Lactobacillus is regulated by differential expression of the pln operons and by two antagonizing response regulators, the activity of which is enhanced upon phosphorylation. Mol Microbiol 47:483-494. doi:10.1046/j.1365-2958.2003.03310.x

Diep DB, Skaugen M, Salehian Z, Holo H, Nes IF (2007) Common mechanisms of target cell recognition and immunity for class II bacteriocins. Proc Natl Acad Sci U S A 104:2384-2389. doi:10. 1073/pnas.0608775104

Dobson A, Cotter PD, Ross RP, Hill C (2012) Bacteriocin production: a probiotic trait? Appl Environ Microbiol 78:1-6. doi:10.1128/AEM. 05576-11

Dunbar KL, Melby JO, Mitchell DA (2012) YcaO domains use ATP to activate amide backbones during peptide cyclodehydrations. Nat Chem Biol 8:569-575. doi:10.1038/nchembio.944

Ennahar S, Sonomoto K, Ishizaki A (1999) Class IIa bacteriocins from lactic acid bacteria: antibacterial activity and food preservation. $\mathrm{J}$ Biosci Bioeng 87:705-716. doi:10.1016/S1389-1723(99)80142-X

FAO/WHO (2001) Report on joint FAO/WHO expert consultation on evaluation of health and nutritional properties of probiotics in food including powder milk with live lactic acid bacteria.
Flühe L, Burghaus O, Wieckowski BM, Giessen TW, Linne U, Marahiel MA (2013) Two [4Fe-4S] clusters containing radical SAM enzyme SkfB catalyze thioether bond formation during the maturation of the sporulation killing factor. J Am Chem Soc 135:959-962. doi:10. 1021/ja310542g

Franz CMAP, van Belkum MJ, Holzapfel WH, Abriouel H, Gálvez A (2007) Diversity of enterococcal bacteriocins and their grouping in a new classification scheme. FEMS Microbiol Rev 31:293-310. doi: 10.1111/j.1574-6976.2007.00064.x

Gabrielsen C, Brede DA, Hernández PE, Nes IF, Diep DB (2012) The maltose $\mathrm{ABC}$ transporter in Lactococcus lactis facilitates high-level sensitivity to the circular bacteriocin garvicin ML. Antimicrob Agents Chemother 56:2908-2915. doi:10.1128/AAC.00314-12

Gabrielsen C, Brede DA, Nes IF, Diep DB (2014a) Circular bacteriocins: biosynthesis and mode of action. Appl Environ Microbiol 80:6854 6862. doi:10.1128/AEM.02284-14

Gabrielsen C, Brede DA, Salehian Z, Nes IF, Diep DB (2014b) Functional genetic analysis of the GarML gene cluster in Lactococcus garvieae DCC43 gives new insights into circular bacteriocin biosynthesis. J Bacteriol 196:911-919. doi:10.1128/JB.01115-13

Garg N, Salazar-Ocampo LM, van der Donk WA (2013) In vitro activity of the nisin dehydratase NisB. Proc Natl Acad Sci U S A 110:72587263. doi:10.1073/pnas. 1222488110

Gargis AS, O'Rourke AL, Sloan GL, Simmonds RS (2009) Prevalence and acquisition of the genes for zoocin A and zoocin A resistance in Streptococcus equi subsp. zooepidemicus. J Mol Evol 68:498-505. doi:10.1007/s00239-009-9221-x

Gavrish E, Sit CS, Cao S, Kandror O, Spoering A, Peoples A, Ling L, Fetterman A, Hughes D, Bissell A, Torrey H, Akopian T, Mueller A, Epstein S, Goldberg A, Clardy J, Lewis K (2014) Lassomycin, a ribosomally synthesized cyclic peptide, kills Mycobacterium tuberculosis by targeting the ATP-dependent protease ClpC1P1P2. Chem Biol 21:509-518. doi:10.1016/j.chembiol.2014.01.014

Gong X, Martin-Visscher LA, Nahirney D, Vederas JC, Duszyk M (2009) The circular bacteriocin, carnocyclin A, forms anion-selective channels in lipid bilayers. Biochim Biophys Acta 1788:1797-1803. doi: 10.1016/j.bbamem.2009.05.008

Grande MJ, López RL, Abriouel H, Valdivia E, Ben Omar N, Maqueda M, Martínez-Cañamero M, Gálvez A (2007) Treatment of vegetable sauces with enterocin AS-48 alone or in combination with phenolic compounds to inhibit proliferation of Staphylococcus aureus. J Food Prot 70:405-411

Guerra NP, Macías CL, Agrasar AT, Castro LP (2005) Development of a bioactive packaging cellophane using nisaplin as biopreservative agent. Lett Appl Microbiol 40:106-110. doi:10.1111/j.1472-765X. 2004.01649.x

Hammami R, Fernandez B, Lacroix C, Fliss I (2013) Anti-infective properties of bacteriocins: an update. Cell Mol Life Sci 70:2947-2967. doi:10.1007/s00018-012-1202-3

Hasper HE, Kramer NE, Smith JL, Hillman JD, Zachariah C, Kuipers OP, de Kruijff B, Breukink E (2006) An alternative bactericidal mechanism of action for lantibiotic peptides that target lipid II. Science 313:1636-1637. doi:10.1126/science.1129818

Haugen HS, Kristiansen PE, Fimland G, Nissen-Meyer J (2008) Mutational analysis of the class IIa bacteriocin curvacin A and its orientation in target cell membranes. Appl Environ Microbiol 74: 6766-6773. doi:10.1128/AEM.01068-08

Heddle JG, Blance SJ, Zamble DB, Hollfelder F, Miller DA, Wentzell LM, Walsh CT, Maxwell A (2001) The antibiotic microcin B17 is a DNA gyrase poison: characterisation of the mode of inhibition. $\mathrm{J}$ Mol Biol 307:1223-1234. doi:10.1006/jmbi.2001.4562

Hegemann JD, Zimmermann M, Xie X, Marahiel MA (2015) Lasso peptides: an intriguing class of bacterial natural products. Acc Chem Res 48:1909-1919. doi:10.1021/acs.accounts.5b00156

Hillman JD, Brooks TA, Michalek SM, Harmon CC, Snoep JL, Van Der Weijden CC (2000) Construction and characterization of an effector 
strain of Streptococcus mutans for replacement therapy of dental caries. Infect Immun 68:543-549. doi:10.1128/IAI.68.2.543-549.2000

Himeno K, Rosengren KJ, Inoue T, Perez RH, Colgrave ML, Lee HS, Chan LY, Henriques ST, Fujita K, Ishibashi N, Zendo T, Wilaipun P, Nakayama J, Leelawatcharamas V, Jikuya H, Craik DJ, Sonomoto K (2015) Identification, characterization, and three-dimensional structure of the novel circular bacteriocin, enterocin NKR-5-3B, from Enterococcus faecium. Biochemistry 54:4863-4876. doi:10.1021/ acs.biochem.5b00196

Holo H, Nilssen O, Nes IF (1991) Lactococcin A, a new bacteriocin from Lactococcus lactis subsp. cremoris: isolation and characterization of the protein and its gene. J Bacteriol 173:3879-3887

Hu CB, Malaphan W, Zendo T, Nakayama J, Sonomoto K (2010) Enterocin X, a novel two-peptide bacteriocin from Enterococcus faecium KU-B5, has an antibacterial spectrum entirely different from those of its component peptides. Appl Environ Microbiol 76: 4542-4545. doi:10.1128/AEM.02264-09

Islam MR, Nishie M, Nagao J, Zendo T, Keller S, Nakayama J, Kohda D, Sahl HG, Sonomoto K (2012) Ring A of nukacin ISK-1: a lipid IIbinding motif for type-a(II) lantibiotic. J Am Chem Soc 134:36873690. doi:10.1021/ja300007h

Iwatani S, Yoneyama F, Miyashita S, Zendo T, Nakayama J, Sonomoto K (2012) Identification of the genes involved in the secretion and selfimmunity of lacticin Q, an unmodified leaderless bacteriocin from Lactococcus lactis QU 5. Microbiology 158:2927-2935. doi:10. 1099/mic.0.062943-0

Joerger MC, Klaenhammer TR (1990) Cloning, expression, and nucleotide sequence of the Lactobacillus helveticus 481 gene encoding the bacteriocin helveticin J. J Bacteriol 172:6339-6347

Kawulka K, Sprules T, McKay RT, Mercier P, Diaper CM, Zuber P, Vederas JC (2003) Structure of subtilosin A, an antimicrobial peptide from Bacillus subtilis with unusual posttranslational modifications linking cysteine sulfurs to alpha-carbons of phenylalanine and threonine. J Am Chem Soc 125:4726-4727. doi:10.1021/ja029654t

Khan H, Flint SH, Yu P-L (2013) Determination of the mode of action of enterolysin A, produced by Enterococcus faecalis B9510. J Appl Microbiol 115:484-494. doi:10.1111/jam.12240

Kjos M, Borrero J, Opsata M, Birri DJ, Holo H, Cintas LM, Snipen L, Hernández PE, Nes IF, Diep DB (2011) Target recognition, resistance, immunity and genome mining of class II bacteriocins from Gram-positive bacteria. Microbiology 157:3256-3267. doi:10. 1099/mic.0.052571-0

Kjos M, Oppegård C, Diep DB, Nes IF, Veening J-W, Nissen-Meyer J, Kristensen T (2014) Sensitivity to the two-peptide bacteriocin lactococcin $\mathrm{G}$ is dependent on UppP, an enzyme involved in cellwall synthesis. Mol Microbiol 92:1177-1187. doi:10.1111/mmi.12632

Klaenhammer TR (1993) Genetics of bacteriocins produced by lactic acid bacteria. FEMS Microbiol Rev 12:39-85. doi:10.1111/j.1574-6976. 1993.tb00012.x

Knerr PJ, van der Donk WA (2012) Discovery, biosynthesis, and engineering of lantipeptides. Annu Rev Biochem 81:479-505. doi:10. 1146/annurev-biochem-060110-113521

Kommineni S, Bretl DJ, Lam V, Chakraborty R, Hayward M, Simpson P, Cao Y, Bousounis P, Kristich CJ, Salzman NH (2015) Bacteriocin production augments niche competition by enterococci in the mammalian gastrointestinal tract. Nature 526:719-722. doi:10.1038/ nature 15524

Kuznedelov K, Semenova E, Knappe TA, Mukhamedyarov D, Srivastava A, Chatterjee S, Ebright RH, Marahiel MA, Severinov K (2011) The antibacterial threaded-lasso peptide capistruin inhibits bacterial RNA polymerase. J Mol Biol 412:842-848. doi:10.1016/j.jmb. 2011.02.060

Lai AC-Y, Tran S, Simmonds RS (2002) Functional characterization of domains found within a lytic enzyme produced by Streptococcus equi subsp. zooepidemicus. FEMS Microbiol Lett 215:133-138. doi: http://dx.doi.org/10.1111/j.1574-6968.2002.tb11382.x
Lee SW, Mitchell DA, Markley AL, Hensler ME, Gonzalez D, Wohlrab A, Dorrestein PC, Nizet V, Dixon JE (2008) Discovery of a widely distributed toxin biosynthetic gene cluster. Proc Natl Acad Sci U S A 105:5879-5884. doi:10.1073/pnas.0801338105

Leroy F, Verluyten J, De Vuyst L (2006) Functional meat starter cultures for improved sausage fermentation. Int J Food Microbiol 106:270 285. doi:10.1016/j.ijfoodmicro.2005.06.027

Li M, Li Yoneyama F, Toshimitsu N, Zendo T, Nakayama J, Sonomoto K (2013) Lethal hydroxyl radical accumulation by a lactococcal bacteriocin, lacticin Q. Antimicrob Agents Chemother 57:3897-3902. doi:10.1128/AAC.00638-13

Liu X, Vederas JC, Whittal RM, Zheng J, Stiles ME, Carlson D, Franz CM, McMullen LM, van Belkum MJ (2011) Identification of an Nterminal formylated, two-peptide bacteriocin from Enterococcus faecalis 710C. J Agric Food Chem 59:5602-5608. doi:10.1021/ jf104751v

Lohans CT, Towle KM, Miskolzie M, McKay RT, van Belkum MJ, McMullen LM, Vederas JC (2013) Solution structures of the linear leaderless bacteriocins enterocin 7A and 7B resemble carnocyclin A, a circular antimicrobial peptide. Biochemistry 52:3987-3994. doi: $10.1021 / \mathrm{bi} 400359 \mathrm{z}$

Lohans CT, Li JL, Vederas JC (2014) Structure and biosynthesis of carnolysin, a homologue of enterococcal cytolysin with D-amino acids. J Am Chem Soc 136:13150-13153. doi:10.1021/ja5070813

Lubelski J, Rink R, Khusainov R, Moll GN, Kuipers OP (2008) Biosynthesis, immunity, regulation, mode of action and engineering of the model lantibiotic nisin. Cell Mol Life Sci 65:455-476. doi:10. 1007/s00018-007-7171-2

Maksimov MO, Pan SJ, Link AJ (2012) Lasso peptides: structure, function, biosynthesis, and engineering. Nat Prod Rep 29:996-1006. doi:10.1039/c2np20070h

Maky MA, Ishibashi N, Zendo T, Perez RH, Doud JR, Karmi M, Sonomoto K (2015) Enterocin F4-9, a novel O-linked glycosylated bacteriocin. Appl Environ Microbiol 81:4819-4826. doi:10.1128/ AEM.00940-15

Maqueda M, Sánchez-Hidalgo M, Fernández M, Montalbán-López M, Valdivia E, Martínez-Bueno M (2008) Genetic features of circular bacteriocins produced by Gram-positive bacteria. FEMS Microbiol Rev 32:2-22. doi:10.1111/j.1574-6976.2007.00087.x

Marciset O, Jeronimus-Stratingh MC, Mollet B, Poolman B (1997) Thermophilin 13, a nontypical antilisterial poration complex bacteriocin, that functions without a receptor. J Biol Chem 272:1427714284. doi:10.1074/jbc.272.22.14277

Martínez Viedma P, Sobrino López A, Ben Omar N, Abriouel H, Lucas López R, Valdivia E, Martín Belloso O, Gálvez A (2008) Enhanced bactericidal effect of enterocin AS-48 in combination with highintensity pulsed-electric field treatment against Salmonella enterica in apple juice. Int J Food Microbiol 128:244-249. doi:10.1016/j. ijfoodmicro.2008.08.014

Martínez B, Fernández M, Suárez JE, Rodríguez A (1999) Synthesis of lactococcin 972, a bacteriocin produced by Lactococcus lactis IPLA 972, depends on the expression of a plasmid-encoded bicistronic operon. Microbiology 145:3155-3161. doi:10.1099/00221287145-11-3155

Martínez B, Rodríguez A, Suárez JE (2000) Lactococcin 972, a bacteriocin that inhibits septum formation in lactococci. Microbiology 146: 949-955. doi:10.1099/00221287-146-4-949

Martin-Visscher LA, Gong X, Duszyk M, Vederas JC (2009) The threedimensional structure of carnocyclin A reveals that many circular bacteriocins share a common structural motif. J Biol Chem 284: 28674-28681. doi:10.1074/jbc.M109.036459

Masuda Y, Zendo T, Sonomoto K (2012) New type non-lantibiotic bacteriocins: circular and leaderless bacteriocins. Benef Microbes 3:312. doi:10.3920/BM2011.0047

Mathavan I, Zirah S, Mehmood S, Choudhury HG, Goulard C, Li Y, Robinson CV, Rebuffat S, Beis K (2014) Structural basis for 
hijacking siderophore receptors by antimicrobial lasso peptides. Nat Chem Biol 10:340-342. doi:10.1038/nchembio.1499

Mathur H, Rea MC, Cotter PD, Hill C, Ross RP (2015) The sactibiotic subclass of bacteriocins: an update. Curr Protein Pept Sci 16:549558. doi:10.2174/1389203716666150515124831

Medema MH, Kottmann R, Yilmaz P, Cummings M, Biggins JB, Blin K, de Bruijn I, Chooi YH, Claesen J, Coates RC, Cruz-Morales P, Duddela S, Düsterhus S, Edwards DJ, Fewer DP, Garg N, Geiger C, Gomez-Escribano JP, Greule A, Hadjithomas M, Haines AS, Helfrich EJN, Hillwig ML, Ishida K, Jones AC, Jones CS, Jungmann K, Kegler C, Kim HU, Kötter P, Krug D, Masschelein J, Melnik AV, Mantovani SM, Monroe EA, Moore M, Moss N, Nützmann H-W, Pan G, Pati A, Petras D, Reen FJ, Rosconi F, Rui Z, Tian Z, Tobias NJ, Tsunematsu Y, Wiemann P, WyckoffE, Yan X, Yim G, Yu F, Xie Y, Aigle B, Apel AK, Balibar CJ, Balskus EP, Barona-Gómez F, Bechthold A, Bode HB, Borriss R, Brady SF, Brakhage AA, Caffrey P, Cheng Y-Q, Clardy J, Cox RJ, De Mot R, Donadio S, Donia MS, van der Donk WA, Dorrestein PC, Doyle S, Driessen AJM, Ehling-Schulz M, Entian K-D, Fischbach MA, Gerwick L, Gerwick WH, Gross H, Gust B, Hertweck C, Höfte M, Jensen SE, Ju J, Katz L, Kaysser L, Klassen JL, Keller NP, Kormanec J, Kuipers OP, Kuzuyama T, Kyrpides NC, Kwon H-J, Lautru S, Lavigne R, Lee CY, Linquan B, Liu X, Liu W, Luzhetskyy A, Mahmud T, Mast Y, Méndez C, Metsä-Ketelä M, Micklefield J, Mitchell DA, Moore BS, Moreira LM, Müller R, Neilan BA, Nett M, Nielsen J, O'Gara F, Oikawa H, Osbourn A, Osburne MS, Ostash B, Payne SM, Pernodet J-L, Petricek M, Piel J, Ploux O, Raaijmakers JM, Salas JA, Schmitt EK, Scott B, Seipke RF, Shen B, Sherman DH, Sivonen K, Smanski MJ, Sosio M, Stegmann E, Süssmuth RD, Tahlan K, Thomas CM, Tang Y, Truman AW, Viaud M, Walton JD, Walsh CT, Weber T, van Wezel GP, Wilkinson B, Willey JM, Wohlleben W, Wright GD, Ziemert N, Zhang C, Zotchev SB, Breitling R, Takano E, Glöckner FO (2015) Minimum information about a biosynthetic gene cluster. Nat Chem Biol 11:625-631. doi:10.1038/nchembio.1890

Melby JO, Nard NJ, Mitchell DA (2011) Thiazole/oxazole-modified microcins: complex natural products from ribosomal templates. Curr Opin Chem Biol 15:369-378. doi:10.1016/j.cbpa.2011.02.027

Montalbán-López M, Sánchez-Hidalgo M, Valdivia E, Martínez-Bueno M, Maqueda M (2011) Are bacteriocins underexploited? Novel applications for old antimicrobials. Curr Pharm Biotechnol 12:12051220. doi:10.2174/138920111796117364

Montalbán-López M, Sánchez-Hidalgo M, Cebrián R, Maqueda M (2012a) Discovering the bacterial circular proteins: bacteriocins, cyanobactins, and pilins. J Biol Chem 287:27007-27013. doi:10. 1074/jbc.R112.354688

Montalbán-López M, Zhou L, Buivydas A, van Heel AJ, Kuipers OP (2012b) Increasing the success rate of lantibiotic drug discovery by synthetic biology. Expert Opin Drug Discov 7:695-709. doi:10. 1517/17460441.2012.693476

Mu F, Masuda Y, Zendo T, Ono H, Kitagawa H, Ito H, Nakayama J, Sonomoto K (2014) Biological function of a DUF95 superfamily protein involved in the biosynthesis of a circular bacteriocin, leucocyclicin Q. J Biosci Bioeng 117:158-164. doi:10.1016/j. jbiosc.2013.06.023

Müller E, Radler F (1993) Caseicin, a bacteriocin from Lactobacillus casei. Folia Microbiol 38:441-446. doi:10.1007/BF02814392

Murphy K, O’Sullivan O, Rea MC, Cotter PD, Ross RP, Hill C (2011) Genome mining for radical SAM protein determinants reveals multiple sactibiotic-like gene clusters. PLoS One 6:e20852. doi:10. 1371/journal.pone.0020852

Neira JL, Contreras LM, OR d 1 P, Sánchez-Hidalgo M, Martínez-Bueno M, Maqueda M, Rico M (2010) Structural characterisation of the natively unfolded enterocin EJ97. Protein Eng Des Sel 23:507-518. doi:10.1093/protein/gzq020
Ni J, Teng K, Liu G, Qiao C, Huan L, Zhong J (2011) Autoregulation of lantibiotic bovicin HJ50 biosynthesis by the BovK-BovR two-component signal transduction system in Streptococcus bovis HJ50. Appl Environ Microbiol 77:407-415. doi:10.1128/AEM.01278-10

Nilsen T, Nes IF, Holo H (2003) Enterolysin A, a cell wall-degrading bacteriocin from Enterococcus faecalis LMG 2333. Appl Environ Microbiol 69:2975-2984. doi:10.1128/AEM.69.5.2975-2984.2003

Nissen-Meyer J, Holo H, Håvarstein LS, Sletten K, Nes IF (1992) A novel lactococcal bacteriocin whose activity depends on the complementary action of two peptides. J Bacteriol 174:5686-5692

Nissen-Meyer J, Rogne P, Oppegård C, Haugen HS, Kristiansen PE (2009) Structure-function relationships of the non-lanthioninecontaining peptide (class II) bacteriocins produced by Grampositive bacteria. Curr Pharm Biotechnol 10:19-37. doi:10.2174/ 138920109787048661

Nissen-Meyer J, Oppegård C, Rogne P, Haugen HS, Kristiansen PE (2010) Structure and mode-of-action of the two-peptide (class-IIb) bacteriocins. Probiotics Antimicrob Proteins 2:52-60. doi:10.1007/ s12602-009-9021-z

Nizet V, Beall B, Bast DJ, Datta V, Kilburn L, Low DE, De Azavedo JC (2000) Genetic locus for streptolysin S production by group A Streptococcus. Infect Immun 68:4245-4254. doi:10.1128/IAI.68.7. 4245-4254.2000

Noll KS, Sinko PJ, Chikindas ML (2011) Elucidation of the molecular mechanisms of action of the natural antimicrobial peptide subtilosin against the bacterial vaginosis-associated pathogen Gardnerella vaginalis. Probiotics Antimicrob Proteins 3:41-47. doi:10.1007/ s12602-010-9061-4

Oman TJ, Knerr PJ, Bindman NA, Velásquez JE, van der Donk WA (2012) An engineered lantibiotic synthetase that does not require a leader peptide on its substrate. J Am Chem Soc 134:6952-6955. doi: 10.1021/ja3017297

Oppegård C, Rogne P, Emanuelsen L, Kristiansen PE, Fimland G, Nissen-Meyer J (2007) The two-peptide class II bacteriocins: structure, production, and mode of action. J Mol Microbiol Biotechnol 13:210-219. doi:10.1159/000104750

Oppegård C, Emanuelsen L, Thorbek L, Fimland G, Nissen-Meyer J (2010) The lactococcin G immunity protein recognizes specific regions in both peptides constituting the two-peptide bacteriocin lactococcin G. Appl Environ Microbiol 76:1267-1273. doi:10. 1128/AEM.02600-09

Ortega MA, Velásquez JE, Garg N, Zhang Q, Joyce RE, Nair SK, van der Donk WA (2014) Substrate specificity of the lanthipeptide peptidase ElxP and the oxidoreductase ElxO. ACS Chem Biol 9:1718-1725. doi:10.1021/cb5002526

Ortega MA, Hao Y, Zhang Q, Walker MC, van der Donk WA, Nair SK (2015) Structure and mechanism of the tRNA-dependent lantibiotic dehydratase NisB. Nature 517:509-512. doi:10.1038/nature13888

Pérez Pulido R, Toledo J, Grande MJ, Gálvez A, Lucas R (2015) Analysis of the effect of high hydrostatic pressure treatment and enterocin AS48 addition on the bacterial communities of cherimoya pulp. Int $\mathrm{J}$ Food Microbiol 196:62-69. doi:10.1016/j.ijfoodmicro.2014.11.033

Piscotta FJ, Tharp JM, Liu WR, Link AJ (2015) Expanding the chemical diversity of lasso peptide MccJ25 with genetically encoded noncanonical amino acids. Chem Commun 51:409-412. doi:10.1039/ c4cc07778d

Rea MC, Sit CS, Clayton E, O'Connor PM, Whittal RM, Zheng J, Vederas JC, Ross RP, Hill C (2010) Thuricin CD, a posttranslationally modified bacteriocin with a narrow spectrum of activity against Clostridium difficile. Proc Natl Acad Sci U S A 107: 9352-9357. doi:10.1073/pnas.0913554107

Rodríguez JM, Martínez MI, Kok J (2002) Pediocin PA-1, a widespectrum bacteriocin from lactic acid bacteria. Crit Rev Food Sci Nutr 42:91-121. doi:10.1080/10408690290825475

Rogne P, Fimland G, Nissen-Meyer J, Kristiansen PE (2008) Threedimensional structure of the two peptides that constitute the two- 
peptide bacteriocin lactococcin G. Biochim Biophys Acta 1784: 543-554. doi:10.1016/j.bbapap.2007.12.002

Rutledge PJ, Challis GL (2015) Discovery of microbial natural products by activation of silent biosynthetic gene clusters. Nat Rev Microbiol 13:509-523. doi:10.1038/nrmicro3496

Sánchez-Hidalgo M, Montalbán-López M, Cebrián R, Valdivia E, Martínez-Bueno M, Maqueda M (2011) AS-48 bacteriocin: close to perfection. Cell Mol Life Sci 68:2845-2857. doi:10.1007/ s00018-011-0724-4

Sass P, Jansen A, Szekat C, Sass V, Sahl H-G, Bierbaum G (2008) The lantibiotic mersacidin is a strong inducer of the cell wall stress response of Staphylococcus aureus. BMC Microbiol 8:186. doi:10. 1186/1471-2180-8-186

Scholz R, Vater J, Budiharjo A, Wang Z, He Y, Dietel K, Schwecke T, Herfort S, Lasch P, Borriss R (2014) Amylocyclicin, a novel circular bacteriocin produced by Bacillus amyloliquefaciens FZB42. J Bacteriol 196:1842-1852. doi:10.1128/JB.01474-14

Simmonds RS, Pearson L, Kennedy RC, Tagg JR (1996) Mode of action of a lysostaphin-like bacteriolytic agent produced by Streptococcus zooepidemicus 4881. Appl Environ Microbiol 62:4536-4541

Sit CS, Lohans CT, van Belkum MJ, Campbell CD, Miskolzie M, Vederas JC (2012) Substitution of a conserved disulfide in the type IIa bacteriocin, leucocin A, with L-leucine and L-serine residues: effects on activity and three-dimensional structure. Chembiochem 13:35-38. doi:10.1002/cbic.201100634

Stepper J, Shastri S, Loo TS, Preston JC, Novak P, Man P, Moore CH, Havlíček V, Patchett ML, Norris GE (2011) Cysteine S-glycosylation, a new post-translational modification found in glycopeptide bacteriocins. FEBS Lett 585:645-650. doi:10.1016/j.febslet.2011.01.023

Stoddard GW, Petzel JP, van Belkum MJ, Kok J, McKay LL (1992) Molecular analyses of the lactococcin a gene cluster from Lactococcus lactis subsp. lactis biovar diacetylactis WM4. Appl Environ Microbiol 58:1952-1961

Suda S, Cotter PD, Hill C, Ross RP (2012) Lacticin 3147-biosynthesis, molecular analysis, immunity, bioengineering and applications. Curr Protein Pept Sci 13:193-204. doi:10.2174/138920312800785021

Swe PM, Cook GM, Tagg JR, Jack RW (2009) Mode of action of dysgalacticin: a large heat-labile bacteriocin. J Antimicrob Chemother 63:679-686. doi:10.1093/jac/dkn552

Turner D, Lamosa P, Rodríguez A, Martínez B (2012) Structure and properties of the metastable bacteriocin Lcn972 from Lactococcus lactis. J Mol Struct 1031:207-210. doi:10.1016/j.molstruc.2012.09.076
Ukuku DO, Fett WF (2004) Effect of nisin in combination with EDTA, sodium lactate, and potassium sorbate for reducing Salmonella on whole and fresh-cut cantaloupet. J Food Prot 67:2143-2150

Uzelac G, Kojic M, Lozo J, Aleksandrzak-Piekarczyk T, Gabrielsen C, Kristensen T, Nes IF, Diep DB, Topisirovic L (2013) A Zndependent metallopeptidase is responsible for sensitivity to LsbB, a class II leaderless bacteriocin of Lactococcus lactis subsp. lactis BGMN1-5. J Bacteriol 195:5614-5621. doi:10.1128/JB.00859-13

Uzelac G, Miljkovic M, Lozo J, Radulovic Z, Tosic N, Kojic M (2015) Expression of bacteriocin LsbB is dependent on a transcription terminator. Microbiol Res 179:45-53. doi: 0.1016/j.micres.2015.06.011

Van Heel AJ, de Jong A, Montalbán-López M, Kok J, Kuipers OP (2013) BAGEL3: automated identification of genes encoding bacteriocins and (non-)bactericidal posttranslationally modified peptides. Nucleic Acids Res 41:W448-W453. doi:10.1093/nar/gkt391

Venugopal H, Edwards PJB, Schwalbe M, Claridge JK, Libich DS, Stepper J, Loo T, Patchett ML, Norris GE, Pascal SM (2011) Structural, dynamic, and chemical characterization of a novel S-glycosylated bacteriocin. Biochemistry 50:2748-2755. doi:10.1021/bi200217u

Wang G, Feng G, Snyder AB, Manns DC, Churey JJ, Worobo RW (2014) Bactericidal thurincin $\mathrm{H}$ causes unique morphological changes in Bacillus cereus F4552 without affecting membrane permeability. FEMS Microbiol Lett 357:69-76. doi:10.1111/1574-6968.12486

Wiedemann I, Böttiger T, Bonelli RR, Schneider T, Sahl HG, Martínez B (2006) Lipid II-based antimicrobial activity of the lantibiotic plantaricin C. Appl Environ Microbiol 72:2809-2814. doi:10. 1128/AEM.72.4.2809-2814.2006

Yan KP, Li Y, Zirah S, Goulard C, Knappe TA, Marahiel MA, Rebuffat S (2012) Dissecting the maturation steps of the lasso peptide microcin J25 in vitro. Chembiochem 13:1046-1052. doi:10.1002/cbic.201200016

Yang X, van der Donk WA (2015) Michael-type cyclizations in lantibiotic biosynthesis are reversible. ACS Chem Biol 10:1234-1238. doi:10. 1021/acschembio.5b00007

Yoneyama F, Imura Y, Ichimasa S, Fujita K, Zendo T, Nakayama J, Matsuzaki K, Sonomoto K (2009a) Lacticin Q, a lactococcal bacteriocin, causes high-level membrane permeability in the absence of specific receptors. Appl Environ Microbiol 75:538-541. doi:10. 1128/AEM.01827-08

Yoneyama F, Imura Y, Ohno K, Zendo T, Nakayama J, Matsuzaki K, Sonomoto K (2009b) Peptide-lipid huge toroidal pore, a new antimicrobial mechanism mediated by a lactococcal bacteriocin, lacticin Q. Antimicrob Agents Chemother 53:3211-3217. doi:10.1128/ AAC.00209-09 